\title{
ON A BROAD CATEGORY OF MULTIVALUED WEAKLY PICARD OPERATORS
}

\author{
HATICE ASLAN HANÇER*, GÜLHAN MINAK** AND ISHAK ALTUN*** \\ *Department of Mathematics, Faculty of Science and Arts \\ Kirikkale University, 71540 Yahsihan, Kirikkale, Turkey \\ E-mail: haslan@kku.edu.tr \\ ** Department of Mathematics, Faculty of Science and Arts \\ Kirikkale University, 71540 Yahsihan, Kirikkale, Turkey \\ E-mail: g.minak.28@gmail.com \\ ***Adress 1: King Saud University, College of Science, \\ Riyadh, Saudi Arabia \\ Adress 2: Department of Mathematics, \\ Faculty of Science and Arts, \\ Kirikkale University, 71450 Yahsihan, Kirikkale, Turkey, \\ E-mail: ishakaltun@yahoo.com.
}

\begin{abstract}
In the present paper, considering a recent technique which is used by Jleli and Samet [10] for fixed points of single-valued maps, we introduce a new concept of multivalued $\theta$-contractions on metric spaces and prove that some of such mappings are multivalued weakly Picard operators on complete metric space. Finally, we give a nontrivial example to show that the class of multivalued $\theta$-contractions is more general than multivalued contractions in the sense of Nadler [14] on complete metric spaces.

Key Words and Phrases: fixed point, multivalued mapping, multivalued contraction, weakly Picard operator.
\end{abstract}

2010 Mathematics Subject Classification: 54H25, 47H10.

Acknowledgments. The authors are grateful to the referees because their suggestions contributed to improve the paper. The second au- thor would like to thank TUBITAK (The Scientific and Technological Research Council of Turkey) for their financial support during his Ph.D. studies.

\section{REFERENCES}

[1] R.P. Agarwal, D. O'Regan, N. Shahzad, Fixed point theorems for generalized contractive maps of Mei-Keeler type, Math. Nachrichten, 276(2004), 3-12.

[2] I. Altun, H.A. Hançer, G. Mınak, On a general class of weakly Picard operators, Miskolc Math. Notes, 16(2015), 25-32.

[3] V. Berinde, Iterative Approximation of Fixed Points, Springer-Verlag, Berlin Heidelberg, 2007.

[4] M. Berinde, V. Berinde, On a general class of multivalued weakly Picard mappings, J. Math. Anal. Appl., 326(2007), 772-782.

[5] V. Berinde, M. Păcurar, The role of the Pompeiu-Hausdorff metric in fixed point theory, Creat. Math. Inform., 22(2013), 35-42. 
[6] Lj.B. Ćirić, Multi-valued nonlinear contraction mappings, Nonlinear Anal., 71(2009), 2716-2723.

[7] P.Z. Daffer, H. Kaneko, Fixed points of generalized contractive multivalued mappings, J. Math. Anal. Appl., 192(1995), 655-666.

[8] Y. Feng, S. Liu, Fixed point theorems for multi-valued contractive mappings and multi-valued Caristi type mappings, J. Math. Anal. Appl., 317(2006), 103-112.

[9] V.I. Istrățescu, Fixed Point Theory: An Introduction, Dordrecht, D. Reidel Publishing Company, 1981

[10] M. Jleli, B. Samet, A new generalization of the Banach contraction principle, J. Ineq. Appl., 2014 2014:38, 8 pp.

[11] T. Kamran, Q. Kiran, Fixed point theorems for multi-valued mappings obtained by altering distances, Math. Comput. Modelling, 54(2011), 2772-2777.

[12] D. Klim, D. Wardowski, Fixed point theorems for set-valued contractions in complete metric spaces, J. Math. Anal. Appl., 334(2007), 132-139.

[13] N. Mizoguchi, W. Takahashi, Fixed point theorems for multivalued mappings on complete metric spaces, J. Math. Anal. Appl., 141(1989), 177-188.

[14] S.B. Nadler, Multi-valued contraction mappings, Pacific J. Math., 30(1969), 475-488.

[15] A. Petruşel, On Frigon-Granas-type multifunctions, Nonlinear Anal. Forum, 7(2002), 113-121.

[16] A. Petruşel, Multivalued weakly Picard operators and applicatinos, Sci. Math. Jpn., 59(2004), 169-202.

[17] S. Reich, Fixed points of contractive functions, Boll. Un. Mat. Ital., 4(1972), no. 5, 26-42.

[18] I.A. Rus, Basic problems of the metric fixed point theory revisited (II), Studia Univ. BabeşBolyai Mathematica, 36(1991), 81-99.

[19] I.A. Rus, A. Petruşel, A. Sîntămărian, Data dependence of the fixed points set of some multivalued weakly Picard operators, Nonlinear Anal., 52(2003), no. 8, 1947-1959.

Received: May 19, 2014; Accepted: November 23, 2014. 